Assessment of Genetic Diversity in Cucumber (Cucumis sativus L.) Genotypes Using Morphological Characters and AFLP Analysis

\author{
Yaşar KARAKURT ${ }^{1}$, Damla GÜVERCIN ${ }^{2}$, Sercan ÖNDER ${ }^{3}$, Özgür İŞLER ${ }^{4}$ \\ ${ }_{1,3,4}$ Isparta Uygulamalı Bilimler Üniversitesi, Tarım Bilimleri ve Teknolojileri Fakültesi, Tarımsal Biyoteknoloji Bölümü, Isparta, ${ }^{2}$ Süleyman \\ Demirel Üniversitesi, Fen-Edebiyat Fakültesi Biyoloji Bölümü, Isparta, Türkiye \\ ${ }^{1}$ https://orcid.org/0000-0003-3914-0652, ${ }^{2}$ https://orcid.org/0000-0002-6639-3818, ${ }^{3}$ https://orcid.org/0000-0002-8065-288X \\ ${ }^{4}$ https://orcid.org/0000-0001-8835-2526 \\ $\bowtie$ : damlaguvercin@sdu.edu.tr
}

\section{ABSTRACT}

For this purpose, 18 cucumber lines were evaluated for their genetic diversity using six morphological characterizations (plant morphology, plant length, length of leaf blade, fruit length, fruit diameter and fruit stem length) and eight AFLP markers. These AFLP primer combinations amplified well and also showed polymorphism. Thus, 1975 AFLP fragments were obtained and 1468 fragments were polymorphic (75.34\%). Dendrograms were drawn using UPGMA (Unweighted Pair Group Method) arithmetical averages and according to the UPGMA dendrogram, the cucumber accessions clustered into two main groups. The genetic distances of the dendrogram varied between 0.92 and 0.96 . Cluster analysis based on morphological data discriminated all lines into three major clusters in UPGMA dendrogram. The similarity coefficient ranged between 0.888 and 0.982 indicating that the cucumber lines used in the study have a low level of genetic variation. Results obtained from the phylogenetic dendrogram by 8 pairs of AFLP primers were consistent with those from the UPGMA clustering analysis, which were in according with the morphological taxonomy on cucumber.

\section{Research Article}

$\begin{array}{ll}\text { Article History } & \\ \text { Received } & : 28.06 .2019 \\ \text { Accepted } & : 09.01 .2020\end{array}$

Keywords

AFLP

Cucumber

Genetic distances

Relationships

\title{
Hıyar (Cucumis sativus L.) Genotiplerinde Genetik Çeşitliliğin Morfolojik Karakterler ve AFLP Analizi Kullanılarak Değerlendirilmesi
}

\section{ÖZET}

$\mathrm{Bu}$ çalışmanın amacı hıyar genotiplerinin morfolojik ve moleküler çeşitliliğini değerlendirmektir. Bu amaçla, altı adet morfolojik özellik (bitki morfolojisi, bitki boyu, yaprak ayası büyüklüğü, meyve uzunluğu, meyve çapı ve meyve sapı uzunluğu) ve sekiz AFLP markeri kullanılarak 18 hıyar hattı genetik çeşitlilik açısından değerlendirilmiştir. Kullanılan AFLP primer kombinasyonları polimorfizm göstermiştir. Çalışma sonucunda 1975 AFLP fragmanı elde edilmiş ve 1468 fragmanın polimorfik olduğu görülmüştür (\%75.34). Dendrogramlar, aritmetik ortalamalar kullanılarak UPGMA (Unweighted Pair Group Method) yöntemiyle çizilmiş ve UPGMA dendrogramina göre hıyar genotipleri iki ana gruba ayrılmıştır. Dendrogramın genetik mesafeleri 0.92 ile 0.96 arasında değişmiştir. Morfolojik verilere dayanan küme analizinde ise UPGMA dendrogramı tüm hatları üç ana kümeye ayırmıştır. Çalışmada kullanılan hıyar hatlarının benzerlik katsayısının 0.888 ile 0.982 arasında değişen düşük bir genetik varyasyon seviyesine sahip olduğu belirlenmiştir. 8 çift AFLP primeri ile oluşturulan filogenetik dendogramlarla, morfolojik taksonomi ile yapılan UPGMA kümeleme analizleriyle oluşturulan dendogramlar örtüşmektedir.

\section{Araştırma Makalesi}

$\begin{array}{ll}\text { Makale Tarihçesi } \\ \text { Geliş Tarihi } & : 28.06 .2019 \\ \text { Kabul Tarihi } & : 09.01 .2020\end{array}$

Anahtar Kelimeler

AFLP

Hiyar

Genetik uzaklık

Akrabalık

To Cite : Karakurt Y, Güvercin D, Önder S, İşler Ö 2020. Assessment of Genetic Diversity in Cucumber (Cucumis sativus L.) Genotypes Using Morphological Characters and AFLP Analysis. KSU J. Agric Nat 23 (3): 577-585. DOI: 10.18016/ksutarimdoga.vi.583844. 


\section{INTRODUCTION}

Cucumber (Cucumis sativus L.) is one of the most economically important and fresh eaten vegetables belonging to the family Cucurbitaceae. Due to its narrow genetic base, the intraspecific genetic diversity in cucumber is relatively low $(3-12 \%)$ as compared to other Cucumis species as revealed in early studies with marker types such as isozymes, RFLPs (restriction fragment length polymorphisms), AFLPs (amplified fragment length polymorphisms) or RAPDs (randomly amplified polymorphic DNAs), (Knerr et al. 1989; Dijkhuizen et al. 1996; Meglic and Staub, 1996; Meglic et al. 1996; Staub et al. 1997; Cavagnaro et al. 2010). However, all methods except AFLP have been reported to have significant disadvantages for this vegetables (Knerr et al. 1989; Waugh and Power, 1992; Staub et al. 1997). As cucumber has a narrow genetic base, it is desirable to develop populations and transfer genes specific to these species using exotic gene sources that control important characters. The evolutions of genetic diversity, relationships and population structure are very important for vegetable characterization and conservation which enhance agricultural production, leading to sustainable development (El-Esawi et al. 2016).

Morphological markers are not widely used because they can be affected by environmental conditions and biochemical markers are not used much due to their limited number in determining the genetic relationships between plant species and varieties. Genetic diversity studies are currently supported by molecular methods, such as molecular markers ( $\mathrm{Li}$ et al. 2019). AFLP is an effective method allowing the identification of genotypes, the construction of a high saturation genetic map and gene cloning (Vos et al. 1995; Scott et al. 2000). Sequence information is not needed in the AFLP technique and a high rate of polymorphism is obtained. AFLP could explore variation throughout the entire genome, including both coding and non-coding regions of DNA and therefore genome-wide variation was allowed (Wu et al. 2019). The advantage of the system is also its high reproducibility (Witkowicz et al. 2003).

The determination of the genetic distance between genotypes is very important for the breeders in terms of the control of genetic resources and genetic diversity and the selection of genotypes for crossing. In this study, the morphological, phenological, yield and quality characteristics of selected cucumber genotypes that are valuable for agricultural production and the differences between genotypes were determined by using AFLP molecular markers.

\section{MATERIALS and METHODS}

\section{Plant material and DNA extraction}

In the study, 18 cucumber genotypes (Table 1) that were estimated to be genetically and morphologically different, were determined and numbered, and some of them were planted and grown in the greenhouse (Aybak and Kaygisız, 2004). Measurements and observations were taken on 10 plants from each genotype and the phenological, morphological, yield and fruit properties were determined based on UPOV criteria. Some seeds were planted in small vials, and leaves were collected from the seedlings and stored at $-80^{\circ} \mathrm{C}$ for DNA isolation. For this purpose, DNA was isolated from $100 \mathrm{mg}$ of leaf material using the CTAB extraction protocol (Weising et al. 1991). DNA quality and concentration were controlled by running each sample on 1\% agarose gel electrophoresis and read on a spectrophotometer at 260 to $280 \mathrm{~nm}$ wavelengths.

Table 1. The samples used in the study Tablo 1. Calışmada kullanılan örnekler

\begin{tabular}{lll}
\hline No. & $\begin{array}{l}\text { Genotypes } \\
\text { Genotipler }\end{array}$ & $\begin{array}{l}\text { Collection site } \\
\text { Toplandiğ yer }\end{array}$ \\
\hline 1 & $147 \mathrm{GY}$ & Turkey, Antalya \\
2 & $159 \mathrm{MO}$ & Turkey, Antalya \\
3 & $523 \mathrm{MO}$ & Turkey, Antalya \\
4 & $529 \mathrm{GY}$ & Turkey, Antalya \\
5 & $224 \mathrm{GY}$ & Turkey, Antalya \\
6 & $225 \mathrm{MO}$ & Turkey, Antalya \\
7 & $1102 \mathrm{MO}$ & Turkey, Antalya \\
8 & $1103 \mathrm{MO}$ & Turkey, Antalya \\
9 & $1140 \mathrm{GY}$ & Turkey, Antalya \\
10 & $315 \mathrm{GY}$ & Turkey, Antalya \\
11 & $316 \mathrm{MO}$ & Turkey, Antalya \\
12 & $1082 \mathrm{GY}$ & Turkey, Antalya \\
13 & $1085 \mathrm{MO}$ & Turkey, Antalya \\
14 & $1095 \mathrm{MO}$ & Turkey, Antalya \\
15 & $309 \mathrm{GY}$ & Turkey, Antalya \\
16 & $1008 \mathrm{MO}$ & Turkey, Antalya \\
17 & $10222 \mathrm{MO}$ & Turkey, Antalya \\
18 & $10226 \mathrm{GY}$ & Turkey, Antalya \\
\hline
\end{tabular}

\section{AFLP analysis}

AFLP reactions were performed with DNA samples obtained from plants using a commercial kit (INVITROGEN) as described (Vos et al. 1995; RoldánRuiz et al. 2000). Eight AFLP primer sets were used to analyze polymorphisms. Total genomic DNA was digested using the two restrictive enzymes EcoRI (New England Biolabs Ltd, NEB) and MseI (NEB). DNA fragments were ligated with EcoRI and MseI adapters using T4 DNA ligase (NEB) for PCR amplification. After the adapters were ligated to the DNA, they were pre-selected to amplify the existing DNA fragments and eliminate the components that were not ligated to the adapter. In the pre-amplification step, genomic DNA was amplified with AFLP pre-amplification primers EcoRI (5'-GACTGCGTACCAATTCA-3') and MseI (5'-GATGAGTCCTGAGTAAC-3'). The preselective amplification reactions were prepared in a 
$25 \mu \mathrm{l}$ reaction mixture, containing $3 \mu \mathrm{l}$ of DNA sample, $1.25 \mu \mathrm{L}$ of each preselective primers $(50 \mathrm{ng} / \mu \mathrm{l}), 2.5 \mu \mathrm{L}$ reaction buffer (10x), $0.5 \mu \mathrm{L}$ dNTP mixtures, 2 units of Taq DNA polymerase (Thermo Scientific) and $16.5 \mu \mathrm{L}$ sterile-double distilled water. The PCR reactions were conducted for 15 cycles of $94{ }^{\circ} \mathrm{C}$ for $3 \mathrm{~min}, 94{ }^{\circ} \mathrm{C}$ for 1 min, $65^{\circ} \mathrm{C}$ for $1 \mathrm{~min}, 70^{\circ} \mathrm{C}$ for $1 \mathrm{~min}$; and then 20 cycles of $94^{\circ} \mathrm{C}$ for $1 \mathrm{~min}, 55^{\circ} \mathrm{C}$ for $1 \mathrm{~min}, 72^{\circ} \mathrm{C}$ for $30 \mathrm{~s}$, plus a final elongation step of $72^{\circ} \mathrm{C}$ for $7 \mathrm{~min}$. The samples were diluted for selective amplification and PCR reactions were performed with a touch-down cycle as follows: 12 cycles of $94{ }^{\circ} \mathrm{C}$ for $45 \mathrm{~s}, 65^{\circ} \mathrm{C}$ for $30 \mathrm{~s}$ (a decrease of $0.7^{\circ} \mathrm{C}$ per cycle) and $72{ }^{\circ} \mathrm{C}$ for $45 \mathrm{~s}$, and then 25 cycles of $94^{\circ} \mathrm{C}$ for $45 \mathrm{~s}, 55^{\circ} \mathrm{C}$ for $30 \mathrm{~s}, 72^{\circ} \mathrm{C}$ for $45 \mathrm{~s}$, and $72^{\circ} \mathrm{C}$ for $5 \mathrm{~min}$ for a final elongation step. The PCR products were separated by $8 \%$ (w/v) polyacrylamide gel electrophoresis.

\section{Morphological Data Analysis}

Overall, 50 days after planting, plant morphology, plant length, the length of leaf blade, fruit length, fruit diameter and fruit stem length were determinned. For each of the 6 morphological characters, the mean and standard deviation values were calculated. These morphological features were determined in 10 randomly chosen plants based on the UPOV criteria (UPOV, 2019).
Data analysis

AFLP data from eight primers were transformed into a binary matrix, scored as present "1", absent " 0 ", for further analyses. The total number of fragments, the number of polymorphic fragments, the percentage of polymorphic loci (\%) and the polymorphic information content (PIC) were calculated using the software GenAlEx 6.5 (Peakall and Smouse, 2006). The dendrogram was constructed using UPGMA (unweighted pair group method with the arithmetic average) based on Nei's genetic distance (Nei, 1972) and the NTSYS ver 2.10 software (Staub et al. 2005). Similarity indices and pairwise genetic distance values were calculated from AFLP data using the UPGMA method and NTSYS software. Clustering analysis was performed using SPSS22.0 software. To examine the correlation between six morphological characters, the pearson correlation coefficient was calculated using IBM SPSS Statistics 22.0 program.

\section{RESULTS and DISCUSSION}

\section{Morphological characterization}

Morphological plant characters including plant length, length of leaf blade, fruit length, fruit diameter and fruit stem length were analyzed in 18 selected cucumber genotypes (Fig. 1).

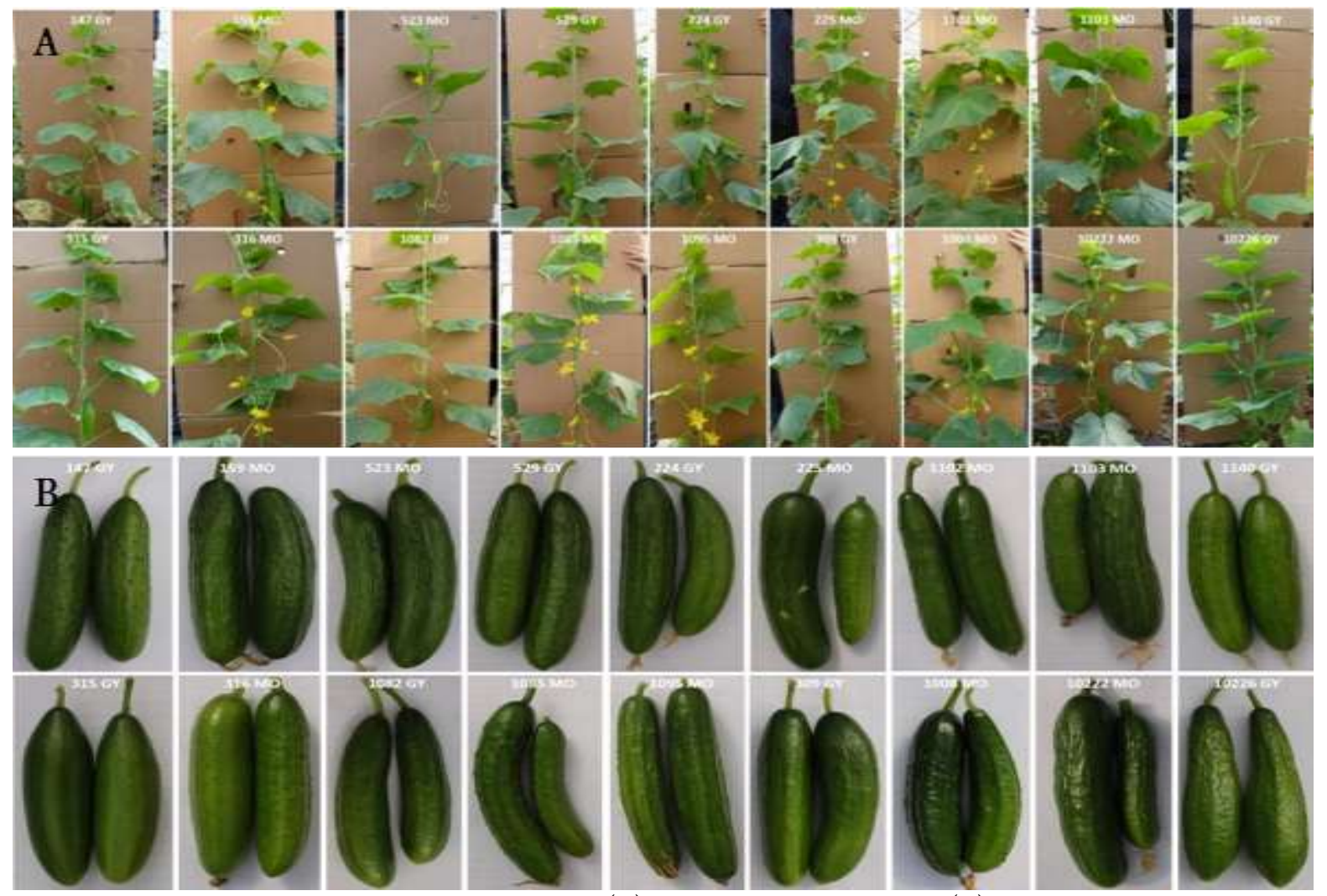

Figure. 1. General growth forms, leaves and flowers (A) and fruit morphology (B) of Cucumber genotypes used for diversity analysis.

Şekil 1. Ceşitlilik analizi için kullanılan hıyar genotiplerinin genel büyüme şekilleri, yaprak ve çiçekleri (A) ile meyve morfolojisi 
The CV (coefficient of variation) values for three of the morphological characters including internodes length, fruit length and fruit stem length indicated a high level of variation (i.e.>10\%), (Table 2). The mean value of plant height was $110.9 \pm 7.66 \mathrm{~cm}$, varied from $69.6 \pm$ $8.1 \mathrm{~cm}(147 \mathrm{GY})$ to $161.1 \pm 5.0 \mathrm{~cm}(316 \mathrm{MO})$ among lines. The mean value of internodes length was $7.7 \pm$ $0.79 \mathrm{~cm}$ and varied from $5.3 \pm 0.7 \mathrm{~cm}$ to $9.2 \pm 0.8 \mathrm{~cm}$ in $147 \mathrm{GY}$ and 1085 MO lines, respectively. The average value of leaf blade length was $21.9 \pm 1.54$ and varied from $17.5 \pm 1.2(523 \mathrm{MO}$, and $529 \mathrm{GY})$ to $30.6 \pm 1.2$ (1102 MO). The mean value of fruit length was $14.8 \pm$ $1.57 \mathrm{~cm}$, varied from $11.4 \pm 1.0 \mathrm{~cm}(315 \mathrm{GY})$ to $17.7 \pm$ $2.4 \mathrm{~cm}$ (10222 MO) lines. The mean value of fruit diameter was $11.8 \pm 1.14 \mathrm{~mm}$ and varied from $9.4 \pm 0.5$ $\mathrm{mm}$ to $14.3 \pm 0.8 \mathrm{~cm}$ in $1095 \mathrm{MO}$ and $224 \mathrm{GY}$ lines, respectively. The average value of fruit stem length was $2.1 \pm 0.55$ and varied from $1.2 \pm 0.4(224 \mathrm{GY}$, and $225 \mathrm{MO})$ to $4.2 \pm 0.6$ (10226 GY) (Table 2).

Based on Pair-wise comparisons among the 18 genotypes, an Euclidean distance matrix was obtained and an unweighted pair-group method using arithmetic mean (UPGMA) dendrogram was constructed. At an Euclidean distance 19.1, three major clusters were obtained based on the morphological characters (Fig. 2), (plant morphology, plant length, length of leaf blade, fruit length, fruit diameter and fruit stem length). A large number of genotypes (12 genotypes) grouped together in cluster I.
Cluster II grouped two genotypes. Four genotypes grouped together in cluster III (Fig. 2). At the 0.05 level of confidence, the results from Pearson correlation analysis appeared that plant height was positively correlated with internodes length, and leaf blade length. Internodes length was positively correlated with leaf blade length but negatively correlated with fruit diameter and fruit stem length (Table 3).

The cucumber has a very narrow gene pool that limits the development of new cucumber varieties (Innark et al. 2013). Genetic diversity data in cucumber genotypes are used in cucumber breeding programs to help determine parental lines. For morphological data, most characters showed an extremely narrow range, indicating that the cucumber genotypes used in the study have a low level of genetic variation. From the correlation analysis of six morphological characters, plant height was positively correlated with internodes length, and leaf blade length. This result was logical because internodes length and leaf blade length were considered as the yield components affecting the plant height. The UPGMA cluster analysis of morphological measurements were effective in distinguishing 18 cucumber ecotypes. The results from this study were consistent with the previous results reported by Innark et al. (2013), which evaluated the morphological data correlation in switchgrass (Cortese et al. 2010) and Chrysanthemum morifolium (Shao et al. 2010).

Table 2. The morphological characteristics of eighteen cucumber lines

Tablo 2. Onsekiz hıyar hattının morfolojik özellikleri

\begin{tabular}{|c|c|c|c|c|c|c|c|}
\hline No. & $\begin{array}{l}\text { Genotypes } \\
\text { Genotipler }\end{array}$ & $\begin{array}{l}\text { Plant } \\
\text { height (cm) } \\
\text { Bitki boyu } \\
\text { (cm) }\end{array}$ & $\begin{array}{l}\text { Internodes } \\
\text { length (cm) } \\
\text { Boğum arası } \\
\text { uzunluğu } \\
\text { (cm) }\end{array}$ & $\begin{array}{l}\text { Leaf blade } \\
\text { length }(\mathrm{cm}) \\
\text { Yaprak ayası } \\
\text { genişliği (cm) }\end{array}$ & $\begin{array}{l}\text { Fruit } \\
\text { length }(\mathrm{cm}) \\
\text { Meyve } \\
\text { uzunluğu } \\
\text { (cm) }\end{array}$ & $\begin{array}{l}\text { Fruit } \\
\text { diameter } \\
(\mathrm{mm}) \\
\text { Meyve çapı } \\
(\mathrm{mm})\end{array}$ & $\begin{array}{l}\text { Fruit stem } \\
\text { length }(\mathrm{cm}) \\
\text { Meyve sap } \\
\text { uzunluğu } \\
(\mathrm{cm})\end{array}$ \\
\hline 1 & $147 \mathrm{GY}$ & $69.6 \pm 8.1$ & $5.3 \pm 0.7$ & $16.3 \pm 0.9$ & $14.7 \pm 1.6$ & $12.0 \pm 1.6$ & $2.5 \pm 0.5$ \\
\hline 2 & $159 \mathrm{MO}$ & $83.1 \pm 8.1$ & $8.0 \pm 0.8$ & $20.8 \pm 1.8$ & $16.6 \pm 1.1$ & $11.4 \pm 0.5$ & $1.4 \pm 0.5$ \\
\hline 3 & $523 \mathrm{MO}$ & $73.9 \pm 9.2$ & $8.1 \pm 0.7$ & $17.5 \pm 1.2$ & $14.0 \pm 1.9$ & $11.2 \pm 0.6$ & $1.6 \pm 0.5$ \\
\hline 4 & 529 GY & $89.5 \pm 8.9$ & $5.8 \pm 0.8$ & $17.5 \pm 1.2$ & $13.6 \pm 1.6$ & $10.9 \pm 1.1$ & $2.5 \pm 0.5$ \\
\hline 5 & $224 \mathrm{GY}$ & $132.7 \pm 7.4$ & $7.4 \pm 0.8$ & $22.2 \pm 1.4$ & $14.7 \pm 0.8$ & $14.3 \pm 0.8$ & $1.2 \pm 0.4$ \\
\hline 6 & $225 \mathrm{MO}$ & $134.2 \pm 7.3$ & $7.3 \pm 0.7$ & $21.6 \pm 0.8$ & $14.8 \pm 1.2$ & $13.0 \pm 1.3$ & $1.2 \pm 0.4$ \\
\hline 7 & $1102 \mathrm{MO}$ & $117.8 \pm 9.4$ & $7.7 \pm 0.9$ & $30.6 \pm 1.2$ & $13.5 \pm 1.2$ & $11.8 \pm 1.0$ & $2.5 \pm 0.5$ \\
\hline 8 & $1103 \mathrm{MO}$ & $113.8 \pm 6.7$ & $8.1 \pm 0.6$ & $27.0 \pm 1.7$ & $12.3 \pm 0.7$ & $11.3 \pm 1.0$ & $1.4 \pm 0.5$ \\
\hline 9 & $1140 \mathrm{GY}$ & $120.7 \pm 9.3$ & $9.1 \pm 1.2$ & $22.3 \pm 2.3$ & $14.7 \pm 3.4$ & $12.8 \pm 2.0$ & $3.4 \pm 0.5$ \\
\hline 10 & 315 GY & $117.4 \pm 8.5$ & $8.3 \pm 0.7$ & $17.7 \pm 2.3$ & $11.4 \pm 1.0$ & $11.7 \pm 1.2$ & $1.7 \pm 0.5$ \\
\hline 11 & $316 \mathrm{MO}$ & $161.1 \pm 5.0$ & $8.1 \pm 1.1$ & $21.1 \pm 0.6$ & $15.7 \pm 1.5$ & $12.5 \pm 1.7$ & $1.5 \pm 0.5$ \\
\hline 12 & $1082 \mathrm{GY}$ & $122.1 \pm 8.5$ & $8.4 \pm 0.7$ & $23.7 \pm 1.9$ & $17.4 \pm 1.3$ & $11.3 \pm 1.2$ & $3.9 \pm 0.7$ \\
\hline 13 & $1085 \mathrm{MO}$ & $142.8 \pm 9.0$ & $9.2 \pm 0.8$ & $24.5 \pm 1.5$ & $17.0 \pm 1.4$ & $11.0 \pm 1.7$ & $1.5 \pm 0.7$ \\
\hline 14 & $1095 \mathrm{MO}$ & $114.0 \pm 8.9$ & $8.5 \pm 0.7$ & $21.4 \pm 2.0$ & $13.2 \pm 1.5$ & $9.4 \pm 0.5$ & $1.8 \pm 0.9$ \\
\hline 15 & 309 GY & $78.7 \pm 6.9$ & $6.6 \pm 0.7$ & $18.1 \pm 1.4$ & $14.2 \pm 1.7$ & $11.7 \pm 1.2$ & $2.4 \pm 0.5$ \\
\hline 16 & $1008 \mathrm{MO}$ & $136.3 \pm 8.2$ & $8.0 \pm 1.2$ & $25.4 \pm 2.8$ & $15.0 \pm 2.2$ & $11.5 \pm 1.0$ & $1.6 \pm 0.5$ \\
\hline 17 & $10222 \mathrm{MO}$ & $98.8 \pm 4.6$ & $8.6 \pm 0.5$ & $27.4 \pm 1.3$ & $17.7 \pm 2.4$ & $12.5 \pm 1.8$ & $1.6 \pm 0.7$ \\
\hline \multirow[t]{2}{*}{18} & $10226 \mathrm{GY}$ & $89.2 \pm 3.8$ & $6.3 \pm 0.7$ & $19.1 \pm 1.4$ & $16.4 \pm 1.7$ & $12.7 \pm 1.3$ & $4.2 \pm 0.6$ \\
\hline & CV (\%) & 6.90 & 10.30 & 7.03 & 10.57 & 9.62 & 26.12 \\
\hline
\end{tabular}




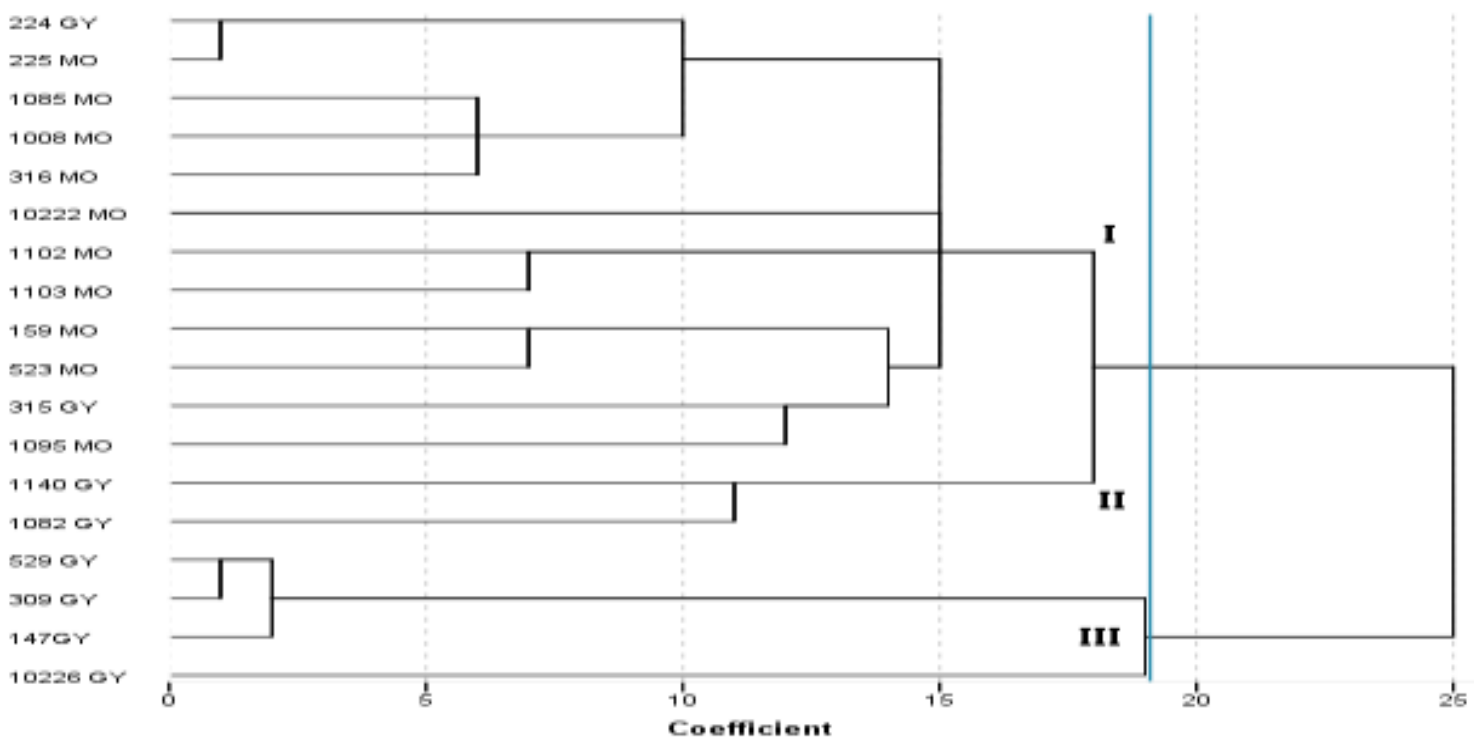

Figure. 2. Dendrogram constructed by UPGMA clustering method based on morphological attributes of eighteen cucumber genotypes

Şekil 2. Onsekiz hıyar genotipinin morfolojik özelliklerine dayanan UPGMA kümeleme yöntemiyle oluşturulan dendogram

Table 3. Pearson correlation analysis of six morphological characters

Tablo 3. Alt morfolojik karakterin Pearson korelasyon analizi

\begin{tabular}{|c|c|c|c|c|c|c|}
\hline & $\begin{array}{l}\text { Plant } \\
\text { height } \\
\text { Bitki } \\
\text { boyu } \\
\end{array}$ & $\begin{array}{l}\text { Internodes } \\
\text { length } \\
\text { Boğum arası } \\
\text { uzunluğu }\end{array}$ & $\begin{array}{l}\text { Leaf blade } \\
\text { length } \\
\text { Yaprak ayası } \\
\text { genişliği }\end{array}$ & $\begin{array}{l}\text { Fruit length } \\
\text { Meyve } \\
\text { uzunluğu }\end{array}$ & $\begin{array}{l}\text { Fruit } \\
\text { diameter } \\
\text { Meyve çapı }\end{array}$ & $\begin{array}{l}\text { Fruit stem } \\
\text { length } \\
\text { Meyve sap } \\
\text { uzunluğu }\end{array}$ \\
\hline Plant height & $* * * *$ & & & & & \\
\hline Internodes length & $\begin{array}{l}0.544^{*} \\
0.020\end{array}$ & $* * * *$ & & & & \\
\hline Leaf blade length & $\begin{array}{l}0.478^{*} \\
0.045\end{array}$ & $\begin{array}{l}0.526^{*} \\
0.025\end{array}$ & $* * * *$ & & & \\
\hline Fruit length & $\begin{array}{l}0.081 \\
0.750\end{array}$ & $\begin{array}{l}0.153 \\
0.546\end{array}$ & $\begin{array}{l}0.192 \\
0.445\end{array}$ & $* * * *$ & & \\
\hline Fruit diameter & $\begin{array}{l}0.212 \\
0.398\end{array}$ & $\begin{array}{l}-0.156 \\
0.536\end{array}$ & $\begin{array}{l}0.041 \\
0.872\end{array}$ & $\begin{array}{l}0.223 \\
0.374\end{array}$ & $* * * *$ & \\
\hline Fruit stem length & $\begin{array}{l}-0.269 \\
0.281\end{array}$ & $\begin{array}{l}-0.249 \\
0.320\end{array}$ & $\begin{array}{l}-0.132 \\
0.602\end{array}$ & $\begin{array}{l}0.226 \\
0.367\end{array}$ & $\begin{array}{l}0.012 \\
0.962\end{array}$ & $* * * *$ \\
\hline
\end{tabular}

Upper number is Pearson correlation coefficient and lower number is $\mathrm{P}$ value.

\section{Polymorphism analysis of AFLP data}

Eight AFLP primer combinations were utilized on eighteen cucumbers (Cucumis sativus L.) genotypes. A total of 1975 scorable fragments were determined, of which $1468 \quad(75.34 \%)$ were polymorphic. This percentage of polymorphic loci $(75.34 \%)$ was higher than that reported by Xixiang et al. (2004) (66\%). They reported that eight pairs of AFLP primers generated 425 scorable bands in total and $66 \%$ of which were polymorphic. In the current study, the number of bands ranged from 116 to 372 with an average of 246.8 (Table 4) and the number of polymorphic fragments for each primer pair varied from 21 to 368 with an average of 183.5. However, the percentage of polymorphic loci ranged from 30.43 to $99.14 \%$ (Table 4). In another study, 92 Turkish cucumbers (Cucumis sativus L. var. sativus) accessions were characterized by using SRAP markers and 153 SRAP fragments were obtained and 138 fragments were polymorphic (90.2\%). The level of polymorphism observed herein is similar to that reported by Kong et al. (2006) but lower than that detected by genomic SSRs (Watcharawongpaiboon and Chunwongse, 2008). The observed PIC values of AFLP markers in this study varied from 0.27 to 0.58 , however, the PIC values were estimated for 45 SSR primer pairs as ranging from 0.11 to 0.78 , with an average of 0.47 (Watcharawongpaiboon and Chunwongse, 2008). Similar results were observed from the cucumber germplasm collection containing a range of ecotypes distributed in China sources by $\mathrm{Hu}$ et al. (2010). In their study, PIC values ranged from 0.185 to 0.642 with an average of 0.374 . 
Table 4. AFLP primer sets and the number of amplified AFLP fragments Tablo 4. AFLP primer setleri ve çoğaltılmıs AFLP bantlarının sayısı

\begin{tabular}{|c|c|c|c|c|}
\hline $\begin{array}{l}\text { Primer sets } \\
\text { Primer setleri }\end{array}$ & $\begin{array}{l}\text { Total number } \\
\text { of fragments } \\
\text { Toplam bant } \\
\text { sayıs }\end{array}$ & $\begin{array}{l}\text { Number of polymorphic } \\
\text { fragments } \\
\text { Polimorfik batların } \\
\text { sayısı }\end{array}$ & $\begin{array}{l}\text { Percentage of } \\
\text { polymorphic loci (\%) } \\
\text { Polimorfik lokusların } \\
\text { yüzdesi }\end{array}$ & $\begin{array}{l}\text { Polymorphic } \\
\text { information } \\
\text { content (PIC) } \\
\text { Polimorfik bilgi } \\
\text { içeriği (PBI) }\end{array}$ \\
\hline EcoRI-ACA/ MseI-CAT & 371 & 203 & 54.72 & 0.48 \\
\hline EcoRI-ACT/ MseI-CTA & 169 & 21 & 30.43 & 0.58 \\
\hline EcoRI-AGC/ MseI-CTT & 231 & 123 & 53.25 & 0.44 \\
\hline EcoRI-ACA/ MseI-CAA & 289 & 266 & 92.04 & 0.36 \\
\hline EcoRI-ACT/MseI-CAG & 372 & 368 & 98.92 & 0.45 \\
\hline EcoRI-AGC/MseI-CAT & 242 & 211 & 87.19 & 0.38 \\
\hline EcoRI-ACA/ MseI-CTA & 185 & 161 & 87.02 & 0.33 \\
\hline EcoRI-ACT/MseI-CTT & 116 & 115 & 99.14 & 0.27 \\
\hline Mean & 246.87 & 183.5 & 75.34 & 0.41 \\
\hline
\end{tabular}

\section{Similarity indices and genetic distance}

Similarity coefficients between cucumber genotypes ranged from 0.888 to 0.982 (Table 5), which was higher than those of reported by $\mathrm{Hu}$ et al. (2010) for EST-SSR markers from the cucumber. Similarity coefficients calculated from EST-SSR data varied from 0.542 to 0.941 with a mean value of 0.792 ( $\mathrm{Hu}$ et al. 2010). The differences in all of these data could be attributed to the differences in the EST analysis. The highest degree of similarity indices (0.982) and the lowest genetic distance (0.018) was observed between $10226 \mathrm{GY}$ and $10222 \mathrm{MO}$, while the lowest degree of similarity (0.888) and the highest genetic distance (0.112) was observed between $1095 \mathrm{MO}$ and $529 \mathrm{GY}$. The second highest similarity indices (0.964) were between $1085 \mathrm{MO}$ and 224 GY, while the second lowest similarity indices (0.893) were between 1082 GY and 1102 MO. Most genotypes evaluated in this study were shown to be very closely related and shared a high degree of genetic similarity. Relatively large genetic distances were observed by RAPD profiling in cucumber (between 0.01 and 0.58) (Horejsi and Staub, 1999) suggesting that these genotypes were more unrelated and RAPD analysis was useful in genotypic differentiation for cucumber. On the contrary, the study performed by Park et al. (2000) determined that AFLP analyses created more polymorphisms than either RFLPs or RAPDs. The selected 37 primer combinations produced approximately 3000 bands, of which 339 bands (11\%) were polymorphic more than RFLPs or RAPDs. Furthermore, they suggested converting the AFLP marker to a dual-primer PCR based marker to enhance its usefulness in cucumber breeding. All these results indicate that both AFLP markers and genotypes used are the most important determinants of the similarity indices and genetic distances.

\section{Cluster analysis}

The similarity matrix for genotypes in cucumber was calculated by using the Dice coefficient method with the NTSYS program. According to the dendrograms, the minimum genetic similarity was $92 \%$ while the maximum similarity between cucumber accessions was $96 \%$. The UPGMA analysis of the marker data resulted in two main groups. The first group included 147GY, $1140 \mathrm{GY}, 529 \mathrm{GY}, 225 \mathrm{MO}, 159 \mathrm{MO}, 1103 \mathrm{MO}$, $1102 \mathrm{MO}, 315 \mathrm{GY}, 316 \mathrm{MO}, 1022 \mathrm{MO}$ in which, $315 \mathrm{GY}$, $316 \mathrm{MO}$ and $1022 \mathrm{MO}$ clustered as a subgroup, whereas 147GY, $1140 \mathrm{GY}, 529 \mathrm{GY}, 225 \mathrm{MO}, 159 \mathrm{MO}$, $1103 \mathrm{MO}$ and $1102 \mathrm{MO}$ clustered as another subgroup. The second group consisted of 523MO, 224 GY, 1085 MO, 1008 MO, 1082 GY, 1095 MO, 309 GY in which 1082 GY, 1095 MO and 309 GY grouped into one subgroup, and 523MO, $224 \mathrm{GY}, 1085 \mathrm{MO}$ and $1008 \mathrm{MO}$ grouped into another subgroup. The cluster analysis of AFLP data showed that the cucumber genotypes were closely related to each other (Figure 3 ).

\section{CONCLUSIONS}

In this study, we selected eight pairs of AFLP informative primers to assess the genetic diversity and relationships among cucumber genotypes collection. AFLP fragments generated by the 8 AFLP primer pairs assayed in this study were 1975 of which 1468 (75.34\%) were polymorphic. The overall mean similarity index calculated based on AFLP fragments amplified using Nei's similarity index ranged from 0.888 to 0.982 with an average of 0.936 . There are only a few studies related the characterization of genetic diversity of cucumber accessions by AFLP. The study revealed a low molecular diversity among the cucumber accessions. Morphological traits of the cucumber accessions were used in conjunction with molecular data to determine germplasm collections. These results may help in the selection of accessions as breeding materials for the development of new cultivars. 


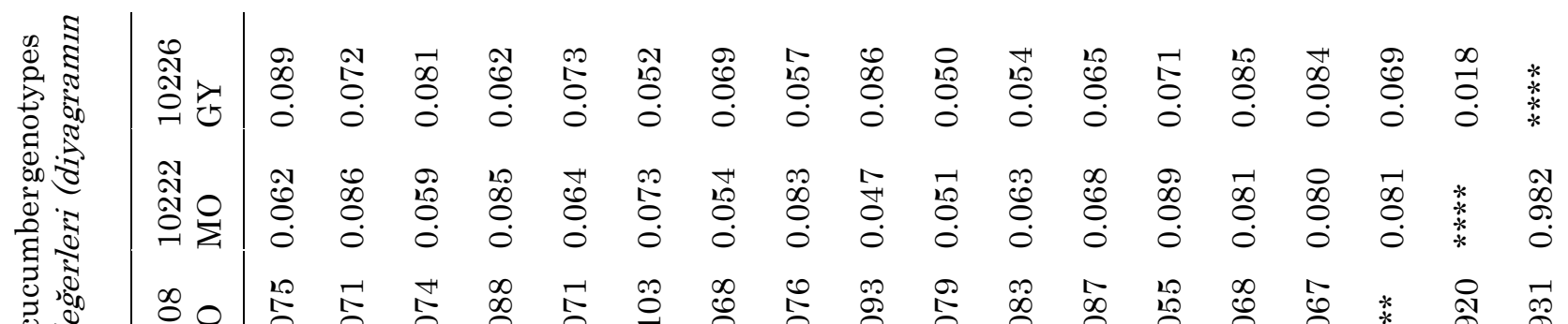

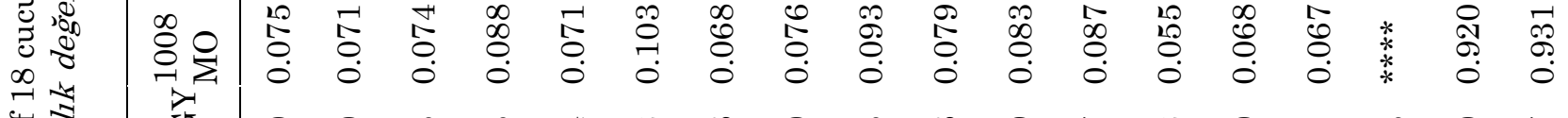

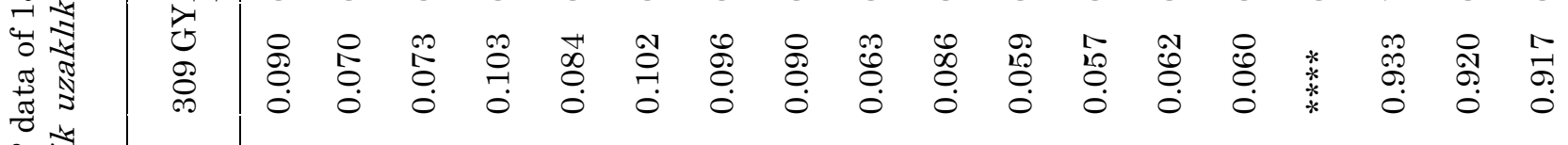
기 :

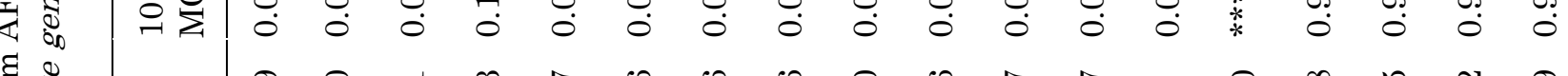

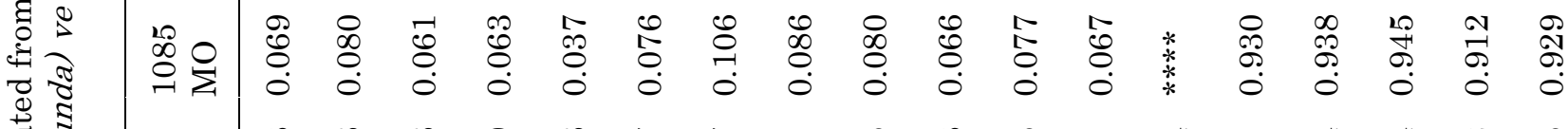
苛 ब

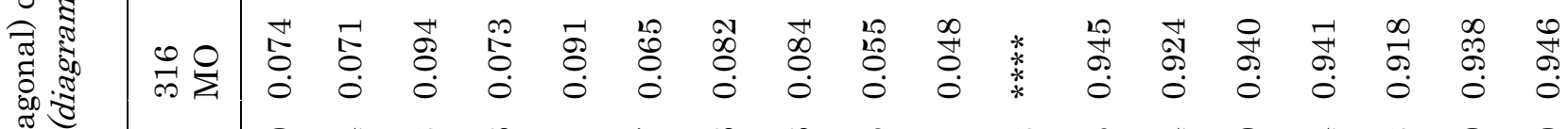

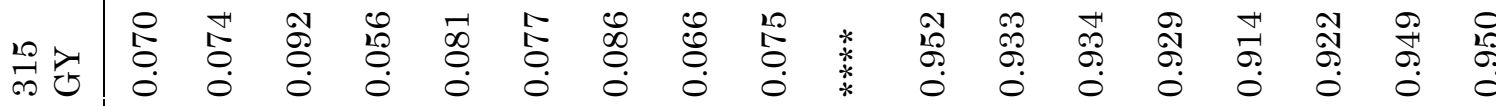

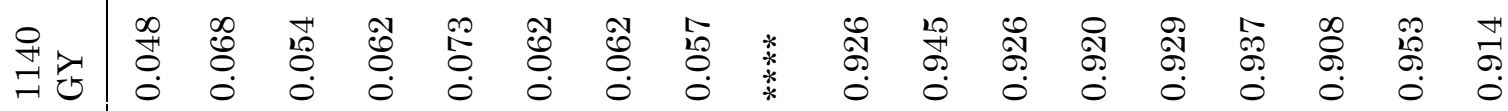

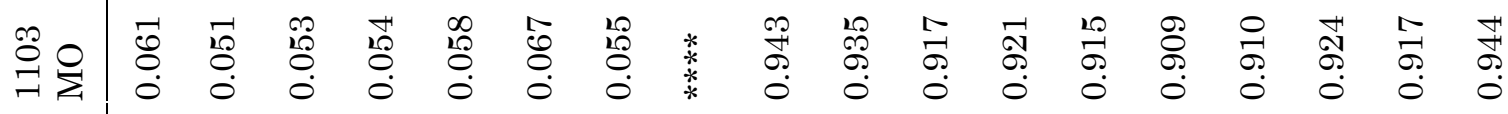

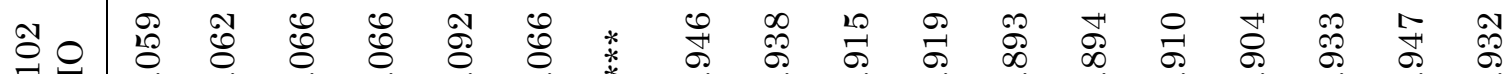
चर

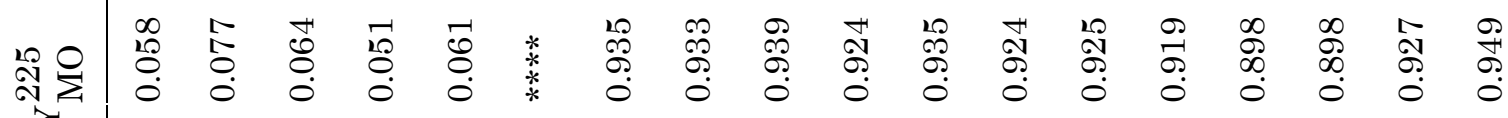

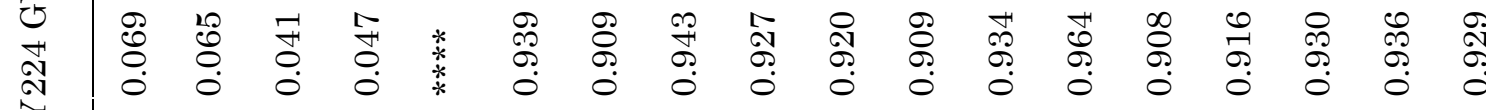

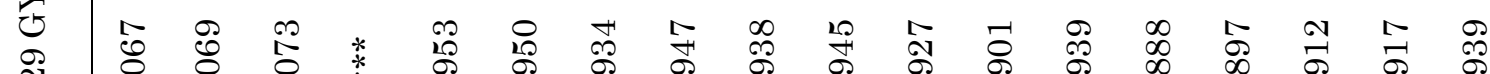

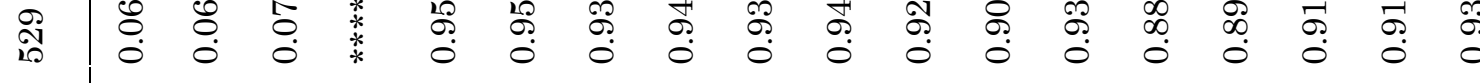

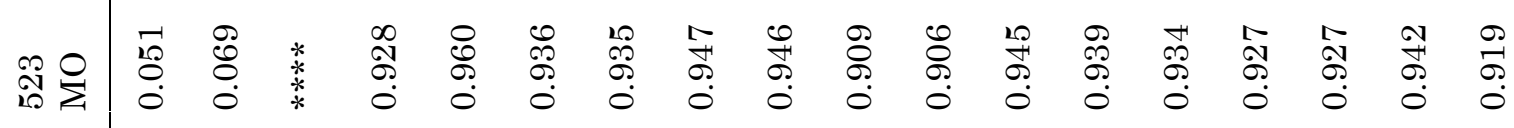

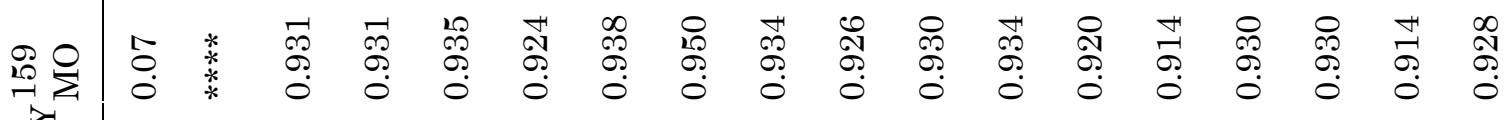
10 16 요의 总 落量

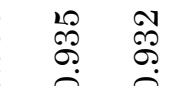

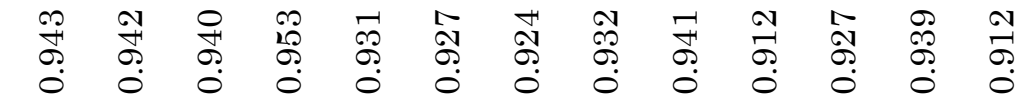

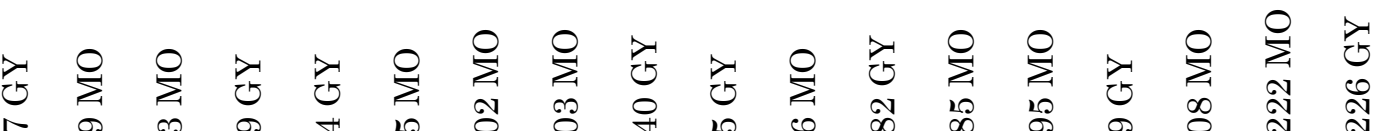
है: : : 琶量 范

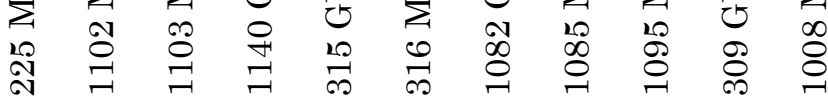




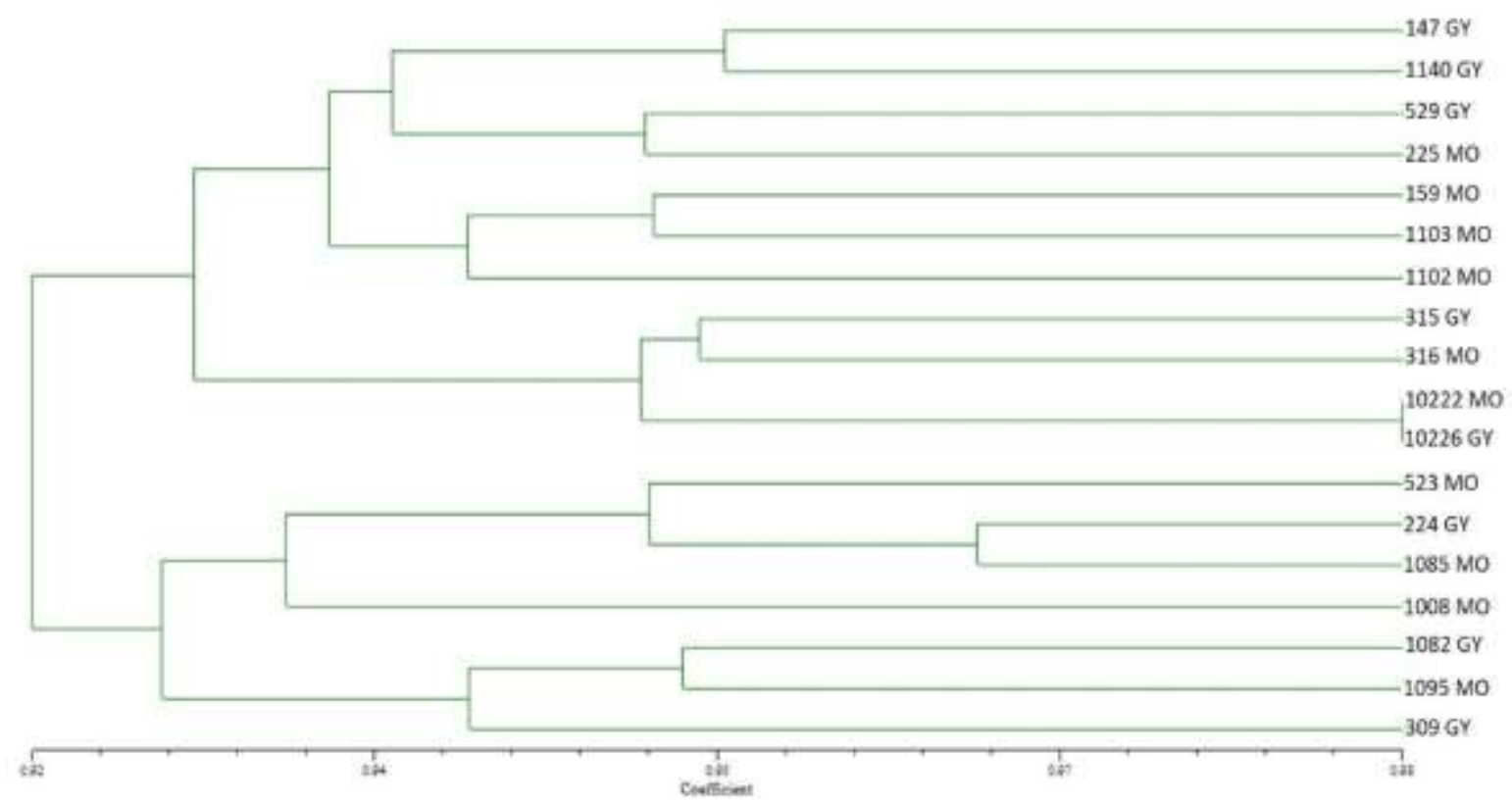

Figure 3. Phylogenetic dendrogram based on Nei's genetic identity of eighteen Cucumis sativus genotypes Şekil 3. Onsekiz Cucumis sativus genotipinin Nei’nin genetik tanımlamasına dayall filogenetik dendogramı

\section{Funding}

Funding for this work was provided by a grant from Suleyman Demirel University.

\section{Statement of Conflict of Interest}

Authors have declared no conflict of interest.

\section{Author's Contributions}

The contribution of the authors is equal.

\section{REFERENCES}

Aybak HÇ, Kaygısız H 2004. Hıyar Yetiştiriciliği. Hasad Yayıncılık, Istanbul, $184 \mathrm{~s}$.

Cavagnaro PF, Senalik DA, Yang L, Simon PW, Harkins TT, Kodira CD, Huang S, Weng Y 2010. Genome-wide characterization of simple sequence repeats in cucumber (Cucumis sativus L.). BMC Genomic, 11: 569.

Cortese LM, Honig J, Miller C, Bonos SA 2010. Genetic diversity of twelve switchgrass populations using molecular and morphological Markers. BioEnergy Research, 3: 262-271.

Dijkhuizen A, Kennard WC, Hayey MJ, Staub JE 1996. RFLP variation and genetic relationships in cultivated cucumber. Euphytica, 90: 79-87.

El-Esawi MA, Germaine K, Bourke P, Malone R 2016. AFLP analysis of genetic diversity and phylogenetic relationships of Brassica oleracea in Ireland. Comptes Rendus Biologies, 339: 163-170.

Horejsi T, Staub JE 1999. Genetic variation in cucumber (Cucumis sativus L.) as assessed by random amplified polymorphic DNA. Genetic Resources and Crop Evolution, 46: 337-350.

$\mathrm{Hu}$ J, Li J, Liang F, Liu L, Si S 2010. Genetic relationship of a cucumber germplasm collection revealed by newly developed EST-SSR markers. Journal of Genetics, 89: 28-32.

Innark P, Khanobdee C, Samipak S, Jantasuriyarat C 2013. Evaluation of genetic diversity in cucumber (Cucumis sativus L.) germplasm using agroeconomic traits and microsatellite markers. Scientia Horticulturae, 162: 278-284.

Knerr LD, Staub JE, Holder DJ, May BP 1989. Genetic diversity in Cucumis sativus L. assessed by at 18 allozyme coding loci. Theoretical and Applied Genetics, 78: 119-128.

Kong Q, Xiang C, Yu Z 2006. Development of ESTSSRs in Cucumis sativus from sequence database. Molecular Ecology Notes, 6: 1234-1236.

Li B, Wang A, Zhang P, Li W 2019. Genetic diversity and population structure of endangered Glehnia littoralis (Apiaceae) in China based on AFLP analysis. Biotechnology \& Biotechnological Equipment, 33: 1-7.

Meglic V, Staub JE 1996. Inheritance and linkage relationships of isozyme and morphological loci in cucumber (Cucumis sativus L.). Theoretical and Applied Genetics, 92: 865-872.

Meglic V, Serquen F, Staub JE 1996. Genetic diversity in cucumber (Cucumis sativus L.): I. A reevaluation of the U.S. germplasm collection. Genetic Resources and Crop Evolution, 43: 533-546.

Nei M 1972. Genetic distance between populations. The American Society of Naturalists, 106: 283-292.

Park YH, Sensoy S, Wye C, Antonise R, Peleman J, Havey MJ 2000. A genetic map of cucumber composed of RAPDs, RFLPs, AFLPs, and loci conditioning resistance to papaya ringspot and zucchini yellow mosaic viruses. Genome, 43: 10031010 . 
Peakall R, Smouse PE 2006. GenAlEx 6.5: genetic analysis in Excel. Population genetic software for teaching and research-an update. Molecular Ecology Notes, 6: 288-295.

Rohlf FJ 2000. NTSYS-pc-Numerical taxonomy and multivariate analysis system, Version 2.10. New York, Exeter Software.

Roldán-Ruiz I, Dendauw J, Van Bockstaele E, Depicker A, De Loose M 2000. AFLP markers reveal high polymorphic rates in ryegrasses (Lolium spp.). Molecular Breeding, 6: 125-134.

Scott KD, Ablett EM, Lee LS, Henry RJ 2000. AFLP markers distinguishing an early mutant of Flame Seedless grape. Euphytica, 113: 245-249.

Shao QS, Guo QS, Deng YM, Guo HP 2010. A comparative analysis of genetic diversity in medicinal Chrysanthemum morifolium based on morphology, ISSR and SRAP markers. Biochemical Systematics and Ecology, 38: 1160-1169.

Staub JE, Box J, Meglic V, Horejsi TF, McCreight JD 1997. Comparison of isozyme and random amplified polymorphic DNA data for determining intraspecific variation in Cucumis. Genetic Resources and Crop Evolution, 44: 257-269.

Staub JE, Chung SM, Fazio G 2005. Conformity and genetic relatedness estimation in crop species having a narrow genetic base: the case of cucumber (Cucumis sativus L.). Plant Breeding, 124: 44-53.

UPOV (The International Union for the Protection of New Varieties of Plants), Guidelines for the Conduct of Tests for Distinctness, Homogeneity, and Stability. https://www.upov.int/portal/ index.html.en , (accessed 13 March 2019).
Vos P, Hogers R, Bleeker M, Reijans M, Van de Lee T, Hornes M, Frijters A, Pot J, Peleman J, Kuiper M, Zabeau M 1995. AFLP: a new technique for DNA fingerprinting. Nucleic Acids Research, 23: 44074414.

Watcharawongpaiboon N, Chunwongse J 2008. Development and characterization of microsatellite markers from an enriched genomic library of cucumber (Cucumis sativus). Plant Breeding, 127: 74-81.

Waugh R, Power W 1992. Using RAPD markers for crop improvement. Trends in Biotechnology, 10: 186-191.

Weising K, Beyermann B, Ramser J, Kahl G 1991. Plant DNA fingerprinting with radioactive and digoxigenated oligonucleotide probes complementary to simple repetitive DNA sequences. Electrophoresis, 12: 159-169.

Witkowicz J, Urbańczyk-Wochniak E, Przybecki Z 2003. AFLP marker polymorphism in cucumber (Cucumis sativus L.) near isogenic lines differing in sex expression. Cellular \& Molecular Biology Letters, 8: 375-381.

Wu WD, Liu WH, Sun M, Zhou JQ, Liu W, Zhang CL, Zhang XQ, Peng Y, Huang LK, Ma X 2019. Genetic diversity and structure of Elymus tangutorum accessions from western China as unraveled by AFLP markers. Hereditas, 156(1): 8.

Xixiang L, Dewei Z, Yongchen D, Di S, Qiusheng K, Jiangping S 2004. Studies on genetic diversity and phylogenetic relationship of cucumber (Cucumis sativus L.) germplasm by AFLP technique. Acta Horticulturae Sinica, 31(3): 309-314. 